\title{
THE EFFECTIVENESS OF CORK FISH (Channa Striatus) AND EGG WHITE SNACK TO IMPROVE BLOOD ALBUMIN LEVEL AND BODY WEIGHT IN TUBERCULOSIS PATIENTS
}

\author{
Tri Marta Fadhilah ${ }^{1 *}$, Elfira Maya Sari ${ }^{2}$ \\ ${ }^{1}$ Bachelor of Nutrition Program, STIKes Mitra Keluarga \\ Jl. Pengasinan Raya, Rawa Semut-Margahayu, East Bekasi, West Java, Indonesia \\ ${ }^{2}$ Diploma of Medical Laboratory Technology Program, STIKes Mitra Keluarga \\ J1. Pengasinan Raya, Rawa Semut-Margahayu, East Bekasi, West Java, Indonesia \\ *Email: trimartafadhilah15@gmail.com
}

\begin{abstract}
Background: Patients with tuberculosis need foods that contain lots of protein and albumin such as cork fish and chicken egg white without yolk to speed up the repair of cells and tissues damaged by Mycobacterium Tuberculosis bacteria.

Objective: The study was conducted to determine the increase in blood albumin levels and body weight in patients with tuberculosis by giving cork fish and egg white snacks.

Methods: This study is an experimental study involving 40 respondents who were randomly selected and divided into intervention and control groups. Each respondent in the intervention group received 2 types of snacks ( 1 brownies and 1 pastels) every day for 15 days (the ratio of cork fish and egg white used was 100gr:70gr), while the control group did not get snacks. To see an increase in albumin levels and body weight in the intervention group before and after the intervention, paired t-test was used, while to see the comparison between the intervention and control groups, an unpaired t-test was used.

Results: The results showed that of all respondents (men aged between 15-80 years), there was an average increase in body weight of $+0.25 \mathrm{~kg}$ (the average before the intervention was $46.05 \mathrm{~kg}$ and the average after the intervention was $47.3 \mathrm{~kg}$ ). In addition, there was an increase in the mean initial albumin level of $+1.7 \mathrm{~g} / \mathrm{L}$ (mean value before intervention was $41.8 \mathrm{~g} / \mathrm{L}$ while after intervention was $43.5 \mathrm{~g} / \mathrm{L}$ ). The results of the t-test analysis showed that there was a significant difference $(\mathrm{p}=0.002)$ between the increase in blood albumin levels in the intervention group and the control group, and a significant difference $(\mathrm{p}=0.004)$ between the increase in body weight in the intervention and control groups after the 15-day snack intervention.

Conclusion: There was an increase in blood albumin levels and body weight in patients with tuberculosis after treatment for 15 days.
\end{abstract}

Keywords: Albumin; Body Weight; Snack; Tuberculosis

\section{INTRODUCTION}

Based on WHO (World Health Organization), the number of tuberculosis (TBC) patients in 2014 is around 9.6 million people in the world. They consist of 5.4 million male, 3.2 million female, and 1 million children. Mortality rate caused by TBC in 1.5 million people is consisting of 890.000 male, 480.000 female and 140.000 children in the same year. ${ }^{1}$ The prevalence of TB cases in Indonesia according to the Indonesian health data profile in 2016 was 156,723 residents; consisting of 95,382 male patients and 61,341 female patients. ${ }^{2}$

Tuberculosis germs attract lungs, but it also can attract other organ such as meninges, bones, joints, urogenital tract, and skin. In the body tissues TB germs can last a long time for several years termed dormant. ${ }^{3}$ Tuberculosis disease transmission is through droplets, it makes the transmission is easier to the surrounding environment. Tuberculosis disease can attract any ages, especially the productive one. Most of pulmonary TBC is in low level economy, so the possibility of nutritional needs is not properly met. ${ }^{4,5}$

If the protein and albumin content is lacking, so healing process will be hampered. Infection can make the nutritional status worse, and poor nutritional status can make it easier to get infected. ${ }^{6}$ Cork fish contain a lot of albumin compared to other fresh fish as much 105.23 $\mathrm{mg} / \mathrm{g}$ with compared to cork fish as much 42.76 
$\mathrm{mg} / \mathrm{g}$ and betutu fish as much $54.09 \mathrm{mg} / \mathrm{g}^{7}$ The male cork fish albumin content of $6.7 \%$, it is lower than the female cork fish that has $8.2 \%{ }^{8}$ The results of research that has been done by giving cork fish extract can affect the increase in albumin levels in the blood and it can increase body weight significantly in outpatients pulmonary tuberculosis. ${ }^{9}$ According to the results, pulmonary tuberculosis patient that was given $500 \mathrm{mg}$ capsule of cork fish in a month is increasing its albumin level. ${ }^{10}$

Egg is an economical food and the egg white is known to contain more albumin than the yolk. 100 grams of purebred chicken egg white contains an average of $10.5 \mathrm{~g}$ of protein, $95 \%$ of which is albumin $9.83 \mathrm{~g} .{ }^{11}$ The results of research that has been carried out in Prof. Dr. Margono Soekarjo Hospital showed that give egg white extract for 10 days increased serum albumin levels by an average of $1.13 \mathrm{~g} / \mathrm{dL}$ in tuberculosis patients with hypoalbuminemia. ${ }^{12}$ The other research was conducted in Dr. Sardjito Hospital Yogyakarta and Panembahan Senopati Hospital in Bantul, the result showed the increase of albumin level in the blood in hypoalbuminemia patients after being given extra 40 grams of ripe egg white juice, 70 grams of fresh fruit and 15 grams of sugar for 7 days given 3 times a day. ${ }^{13}$ Albumin is an important protein needed by human body especially in the process of healing. Most of albumin in the plasma reaches $60 \%$ while the normal value in the blood is around 3.5 to $5 \mathrm{~g} / \mathrm{dL}$, it is useful to help the growth of new cell tissue and to quicken the recovery of damaged body tissue. ${ }^{14}$ During this time cork fish and egg whites are only made in the form of extracts and capsules, whereas cork fish and egg whites can be processed into a variety of foods such as snacks (brownies and pastels).
Based on the description above, it is expected to use cork fish and egg whites to make snacks such as brownies and pastels, it is intended to be able to increase the immune system, improve nutritional status and speed up the healing process in tuberculosis. ${ }^{15}$ In addition, this study is expected to reduce the prevalence of TB patients in Indonesia especially in Bekasi City.

\section{METHOD}

This research was conducted using an experimental study design to 40 tuberculosis patients in several areas of the Bekasi City Health Center such as the Karang Kitri Health Center, Bekasi Jaya Health Center and Duren Jaya Health Center. The sampling method used is random sampling based on predetermined inclusion and exclusion criteria. The inclusion criteria in determine of the sample in study are as follows TB patients registered at Karang Kitri Health Center, Duren Jaya Health Center, Aren Jaya Health Center and Bekasi Jaya Health Center, TB patients who are treatment for 6 months at the health center and TB patients who are ready to be treatment.

Calculation of the number of samples carried out using the Slovin formula to obtain 40 tuberculosis patients who were divided into control and intervention groups. Based on the Picture 1, the symbols $\mathrm{O} 1$ and $\mathrm{O} 2$ are the examination of body weight and albumin before treatment while $\mathrm{O} 3$ and $\mathrm{O} 4$ is an examination of body weight and albumins after treatment, then $\mathrm{K}$ is control and $\mathrm{P}$ is treatment. This research has registered the code of ethics from UHAMKA with the number 03/19.03/008.

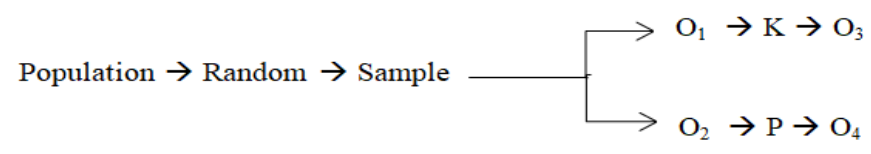

Picture 1. Research design plot

Experiments were carried out by giving brownies and pastels made of cork fish and egg whites to the intervention group to see their effect on increasing albumin levels and body weight in TB patients. The ingredients of the brownies given consist of 120 grams of low protein flour, 35 grams of powdered chocolate, 100 grams of dark cooking chocolate, 125 grams of melted butter, 6 white eggs, 3 yolks, 100 grams of sugar, 1 tsp vanilla. powder, $1 / 2$ tsp baking powder, SP 1/4 tsp, cork fish flesh 100 grams, 1/4 teaspoon salt and cheese as topping. While the ingredients for the pastels provided consisted of 250 grams of low protein wheat flour, $30 \mathrm{ml}$ of cooking oil, 50 grams of margarine, $80 \mathrm{ml}$ of water, $1 / 2 \mathrm{tsp}$ sugar, 1/2 tsp salt salt for the shell. and the filling 
is made of cork fish fill filled in 250 grams blended, 100 grams of scrambled egg whites, 100 grams diced carrots, 100 grams diced potatoes, finely sliced celery leaves 2 sticks, finely sliced leeks 2 sticks, finely chopped onions 50 grams, garlic puree 2 cloves, onion puree 4 cloves, 1 tsp sugar, 1 tsp salt, pepper $1 / 2$ tsp powder, and oil for sautéing.

The initial step of the study was to check the level of albumin in the respondent's blood, then for the next 15 days, give the intervention group 2 snacks (brownies and pastels) weighing 50 grams 1 time each day in a row to the intervention group. After the intervention for 15 days, the next step is to re-check the albumin level in the respondent's blood.

The step of checking albumin levels is done by taking the respondent's blood and then converting it into serum by centrifugation. The

Table 1. Gender, age, level of education, occupation, income and number of family members of the study subjects

\begin{tabular}{|c|c|c|c|c|c|}
\hline \multicolumn{2}{|l|}{ Characteristics } & \multicolumn{2}{|c|}{ Control } & \multicolumn{2}{|c|}{ Treatment } \\
\hline & & $\mathrm{n}$ & $\%$ & $\mathrm{n}$ & $\%$ \\
\hline \multirow[t]{2}{*}{ Gender } & Male & 9 & 45 & 10 & 50 \\
\hline & Female & 11 & 55 & 10 & 50 \\
\hline \multirow[t]{6}{*}{ Age } & Late teens $(17-25 \mathrm{yr})$ & 1 & 5 & 1 & 5 \\
\hline & Early adulthood (26-35 yr) & 8 & 40 & 6 & 30 \\
\hline & Late adulthood (36-45 yr) & 5 & 25 & 3 & 15 \\
\hline & Early elderly (46-55 yr) & 3 & 15 & 7 & 35 \\
\hline & Late elderly (56-65 yr) & 1 & 5 & 1 & 5 \\
\hline & Old man $(>65 \mathrm{yr})$ & 2 & 10 & 2 & 10 \\
\hline \multirow[t]{3}{*}{ Education level } & Elementary & 9 & 45 & 11 & 55 \\
\hline & High School & 10 & 50 & 7 & 35 \\
\hline & higher education & 1 & 5 & 2 & 10 \\
\hline \multirow[t]{4}{*}{ Job } & Trader & 6 & 30 & 3 & 15 \\
\hline & Labors & 6 & 30 & 9 & 45 \\
\hline & Entrepreneur & 4 & 20 & 2 & 10 \\
\hline & Housewife & 4 & 20 & 6 & 30 \\
\hline \multirow[t]{4}{*}{ Income } & Highest income (> Rp 3.5000.000/month) & 6 & 30 & 3 & 15 \\
\hline & High income (Rp 2.600.000 - Rp 3.500.000/month) & 2 & 10 & 3 & 15 \\
\hline & Middle income (Rp 1.500 .000 - Rp 2.500.000/month) & 8 & 40 & 6 & 30 \\
\hline & Lowest income $(<\operatorname{Rp} 1.500 .000)$ & 4 & 20 & 8 & 40 \\
\hline \multirow{3}{*}{$\begin{array}{l}\text { Number of } \\
\text { family } \\
\text { dependents }\end{array}$} & Small family 1-3 people & 11 & 55 & 3 & 15 \\
\hline & Middle family $4-6$ people & 8 & 40 & 12 & 60 \\
\hline & Big family $>6$ people & 1 & 5 & 5 & 25 \\
\hline \multicolumn{2}{|l|}{ Total respondent } & 20 & 100 & 20 & 100 \\
\hline
\end{tabular}

The result shows that the characteristics data of respondents in the control group were dominated by males than females; it is 11 people solution is made in the form of blanks and serum samples. A blank solution was made by using 10 $\mathrm{L}$ distilled water pipelines and then adding $1 \mathrm{~mL}$ of albumin reagent. Blanks and samples were incubated for 5 minutes at $37^{\circ} \mathrm{C}$. Then, they were measured for their albumin levels using a semiauto chemistry analyzer at a wavelength of 578 nm.

\section{RESULTS \\ Respondent Characteristics}

Respondent distribution was distributed in 2 groups, the first is control group and the other is intervention group. The distribution of gender, age, education level, job, income and number of family members can be seen in the Table 1. 
control group is mostly in early adulthood (26-35 $\mathrm{yr}$ ), which is 8 people $(40 \%)$. Whereas in the intervention group, most of the age group of the elderly (46-55), is 7 people (35\%). The data of education level in the control group is dominated by senior high school education level, it consists of 10 people $(50 \%)$. While the intervention group is dominated by elementary level, it is 11 people (55\%). The data of respondent jobs in the control group is dominated by traders and laborers, it reaches 6 people $(30 \%)$. While the intervention group is dominated by housewives, it is 9 people $(45 \%)$.

The data of respondent salary in the control group is mostly in the middle level ( $\mathrm{Rp}$ 1.500.000 - Rp 2.500.000 each month), it reaches 8 people $(40 \%)$, whereas the intervention group is mostly in the lower level $(<\mathrm{Rp}$ $1.500 .000)$ it is 8 people (40\%). The data of the number of family members in the control group is mostly in 1-3 small family dependents, namely 11 people $(55 \%)$. While in the intervention group, the highest number of dependents was 4

Tabel 2. The difference in body weight $(\mathrm{kg})$ in the group that got the snack and the group that didn't get the snack

\begin{tabular}{lccc}
\hline \multirow{1}{*}{ Group } & Before & After & $p$ \\
\cline { 2 - 3 } & Mean \pm SD & Mean \pm SD & \\
\hline Control & $36.84 \pm 58.56$ & $37.11 \pm 59.19$ & 0.083 \\
Treatment & $37.23 \pm 54.86$ & $39.91 \pm 55.29$ & 0.015 \\
$p$ & 0.601 & 0.856 & \\
\hline
\end{tabular}

The Effect of Giving Snack on The Increase of Albumin Level

Twenty patients of the control group and 20 patients of the intervention group were taken as the sample of albumin level on TB patients in the healing process in the public health center. Based on Table 3, the albumin level in the intervention group is lower than the control group with a p-value is 0.902 which means there is no difference. Then, the albumin level after giving snacks in the intervention group is higher to 6 people, it consists of 12 people $(60 \%)$. The most research respondent data is $<\mathrm{Rp} 1.500 .000$ / month. This will give an impact on the availability of food and nutritional intake needs in the family (Table 1).

\section{The Effect of Given Brownies on Weight Gain}

Result data shows that the bodyweight of the control group was normal after treatment. Table 2 shows that the bodyweight of the intervention group is lower than the control one with a value of $\mathrm{p}=0.601$ which means there are no differences. The bodyweight of the intervention group is higher than the control one with a value of $p=0.856$, which means it has no differences. The data of the control group before and after treatment is a value of $p=0.083$, which means there is no difference between before and after treatment. Then, the data of the intervention group before and after treatment is the value of $\mathrm{p}=0.015$, it means that there is some difference in body weight before and after treatment.

Tabel 3. Differences in albumin levels (g/dL) in the group that got snacks and the group that didn't get snacks

\begin{tabular}{lccc}
\hline \multirow{1}{*}{ Group } & Before & After & $p$ \\
\cline { 2 - 3 } & Mean \pm SD & Mean \pm SD & \\
\hline Control & $33.42 \pm 46.18$ & $35.98 \pm 47.62$ & 0.192 \\
Treatment & $39.19 \pm 45.91$ & $39.84 \pm 48.06$ & 0.001 \\
$p$ & 0.902 & 0.185 & \\
\hline
\end{tabular}




\section{DISCUSSION}

The result shows that male tuberculosis patients have more number than the female one. It is in line with study ${ }^{16,17,18}$ that says tuberculosis patient is more dominated by male. Based on the result, most respondents aged 26-35 years (early adulthood) both in the control and intervention groups with a total of 70 people, it belongs to productive age. This is in line with the statement from Sari and Fauziah ${ }^{19}$ said that $74.4 \%$ of people with tuberculosis occur at productive age. The highest number of tuberculosis cases is in the age of $20-29$ years $(46.8 \%)$, while the lowest number of tuberculosis cases occurs at the age above 60 years. ${ }^{20}$ This is as same as the results of other studies that the smallest percentage of tuberculosis patients occurs at age $\geq 65$ years. $^{21}$ Education level is one of the risk factors for transmitting Tuberculosis. Based on the results of the study, most respondents' education level is elementary education. This low level of education will affect the understanding of Tuberculosis. Communities with high levels of education are seven times more aware of pulmonary TB (symptoms, modes of transmission, treatment), it compared to people who only have basic education or lower. A low level of education is associated with a low level of awareness of pulmonary TB transmission. ${ }^{22}$

The majority of TB patients is a laborer. Sajith (2015) said that TB patients mostly in blue collar workers. Adults are susceptible to TB. One of the reasons is their work activities; it is more likely exposed to TB..$^{19}$ In addition, blue collar workers are vulnerable to fatigue. Factors of physical fatigue can cause immunity decrease and it can be easily susceptible to infection. The factory workers tend to work in a closed place without ventilation, it causes TB germs easily to spread to the environment. As Siregar's said that work in damp places and with poor lighting and ventilation increases the risk of transmission at work. ${ }^{23}$ The most research respondent data is $<\mathrm{Rp} 1.500 .000$ / month. This will give an impact on the availability of food and nutritional intake needs in family. Based on the result, the most dependents are 4-6 people. The Central Statistics Agency in Purwanto \& Taftazani grouped the number of dependents into three groups, namely small family dependents (1-3 people), medium family dependents (4-6 people), and large family dependents (more than 6 people). ${ }^{24}$

The data of intervention group before and after treatment is value of $p=0.015$, it means that there is some different of body weight before and after treatment. This is same as the result of Dewi, there is significant increase on the body weight and albumin level of $\mathrm{Tb}$ patients between the intervention group and the control group with significant $\mathrm{P}$ value is 0.003 and $0.028 .{ }^{9}$ Decreasing body weight is early indication beside shortness of breath, coughing up blood, chest pain, weak body, appetite or ever coughing up blood, sweating at night even though inactivity, and fever for more than a month. ${ }^{25}$

The treatment of giving cork fish and egg white snack (brownies and pastels) are 50 grams during 15 days. The albumin content in pastels is $234.61 \% \mathrm{w} / \mathrm{w}$ per 100 grams while albumin content in brownies is $459.29 \% \mathrm{w} / \mathrm{w}$ per 100 grams. The result shown significant towards the increase of albumin on TB patient, which $\mathrm{P}$ value is 0.001 . Based on Mustafa, Widodo, Kristianto, (2012), Cork fish extract in hypoalbuminemia patients significantly increased serum albumin and correlated with $\mathrm{p}$ value $=0.001 .{ }^{25}$ Giving extract as much as 2 $\mathrm{kg}$ for 5 days can increase the level of albumin $1.8 \mathrm{~g}$ / 100ml under normal conditions,> $3.5 \mathrm{~g} / 100 \mathrm{ml}$. According to the results of the study for 1 month given $500 \mathrm{mg}$ capsules of cork fish extract in patients with pulmonary tuberculosis can increase levels of albumin in the blood. ${ }^{10}$

\section{CONCLUSIONS}

The treatment of giving cork fish and egg white snacks (brownies and pastels) during 15 days can increase body weight and blood albumin level in tuberculosis patients. Recommendation for this study is snack can be consumed every day while continuing to consume other nutritional intakes to increase blood albumin levels and body weight in TB patients.

\section{REFERENCES}

1. World Health Organization. Global Tuberculosis Report. 2015

2. Kementrian Kesehatan RI. Indonesia Health Profile Data and Information 2016. Jakarta: Kemenkes Ri. 2017

3. Kementrian Kesehatan RI. Pedoman Nasional Penanggulangan Tuberkolosis Cetakan ke-8. Jakarta: Kemenkes RI. 2021

4. Tabrani, I. Konversi sputum BTA pada fase intensif TB paru kategori I antara kombinasi dosis tetap (KDT) dan obat anti tuberkulosis (OAT) generik di RSUP. H. Adam Malik Medan. Universitas Sumatra Utara. Tesis. 2017.

5. Manalu HSP. Faktor-faktor yang mempengaruhi TB paru dan upaya penanggulangannya. Jurnal Ekologi Kesehatan. 2010; 9(4): 1340 - 1346.

6. Supariasa IDN. Penilaian Status Gizi. Jakarta: Buku Kedokteran EGC. 2001

7. Prastari C, Yasni S, Nurilmala M. Karakteristik protein ikan gabus yang berpotensi sebagai antihiperglikemik. JPHPI. 2017; 20(2): 413-423.

8. Suprayitno E. Ikan Gabus Sumber Protein Tinggi. Serial online 1. 2008. Available from : http://suaramuhammadiyah.com. 
9. Dewi MK. Pengaruh pemberian ekstrak ikan gabus terhadap kenaikan kadar albumin dalam darah dan berat badan pasisen rawat jalan tuberkulosis paru di rumah sakit paru Jember. Universitas Jember. Skripsi. 2011.

10. Wijaya GK 2015. Pengaruh kapsul ekstrak ikan gabus (chanastriata) terhadap kadar albumin pada pasien tuberkulosis paru pengobatan fase intensif. Universitas Jember. Skripsi. 2015

11. Persatuan Ahli Gizi Indonesia. Tabel Komposisi Pangan Indonesia. Jakarta: PT Elex Media Komputindo. Jakarta. Edisi 1. 2008. p 42.

12. Prastowo A, Lestariana W, Nurdjanah S, Sutomo R. Keefektifan ekstra putih telur terhadap peningkatan albumin dan penurunan IL-1 $\beta$ pada pasien tuberkulosis dengan hipoalbuminemia. Jurnal Gizi Klinik Indonesia 2014;10(3):111-8.

13. Syamsitun NH \& Siswati T. Pemberian ekstrak jus putih telur terhadap kadar albumin dan hb pada penderita hipoalbuminemia. Jurnal Gizi Klinik Indonesia. 2015; 12(2): 54-61.

14. Jaya PJ. Manfaat Ikan Kutuk (yang Ikannya hampir Punah). 2009. Available from: http://anggakoe.wordpress.com.

15. Nurpudji A. Penyuluhan Gizi Pemberian Soy Protein dan Perbaikan Status Gizi Penderita Tuberculosis di Makassar. 2006. Available from: http//www.nurpujiastuti.wordpress.com/2006/05. \{ 09.

16. Lestari P, Endaryanto A, Sahiratmadja E, Suharto. Status gizi dan status besi anak kontak tuberkulosis serta peranannya dalam kejadian sakit. JBP, 2011; 13(2): 131-136.

17. Kurniasari RAS, Suhartono S, Cahyo K. Faktor risiko kejadian tuberkulosis paru di Kecamatan Baturetno Kabupaten Wonogiri. Media Kesehatan Masyarakat Indonesia. 2012; 11(2): 198-204.

18. Buntuan V. Gambaran Basil Tahan Asam (BTA) positif pada penderita diagnosa klinis tuberkulosis paru di rumah sakit islam Sitti Maryam Manado periode Januari 2014 s/d Juni 2014. Jurnal eBiomedik (eBM). 2014; 2(2): 1-8.

19. Sari IS, Fauziah M. Faktor risiko yang berhubungan dengan kejadian TB paru BTA (+) di wilayah kerja Puskesmas Petamburan Kota Jakarta Pusat Tahun 2012. Jurnal kedokteran dan Kesehatan. 2014; 10(2): 216

20. Soetikno DR, Derry D. Kesesuaian antara foto toraks dan mikroskopis sputum pada evaluasi respons pengobatan tuberkulosis paru setelah enam bulan pengobatan. Majalah Kedokteran Bandung, 2011; 43(3): 140-145.

21. Sihombing H, Sembiring H, Amir Z, Sinaga YMB. Pola resistensi primer pada penderita TB paru kategori I di RSUP H. Adam Malik Medan. Respir Indo. 2012; 32(3): 138-145.

22. Panjaitan. Karakteristik penderita tuberculosis paru dewasa rawat inap di RS umum DR. Soedarso periode September-November 2010. Program Studi Pendidikan Dokter Universitas Tanjung Pura Pontianak. Naskah publikasi Universitas Tanjung Pura Pontianak. 2012.

23. Sajith M, Thomas,A, Kothia, JJ, Chandrakar, B, \& Bargaje, MD. Socio-Demographic characteristics of tuberculosis patients in a tertiary care hospital. International Journal of Medical and Health Research, 2015: 1(3); 25-28.

24. Siregar AF. Hubungan kondisi fisik rumah dan pekerjaan dengan kejadian tuberculosis paru di Desabandar Khalipah Kecamatan Percut Sei 12 Tuan Tahun 2015. Naskah Publikasi, Fakultas Kesehatan Masyarakat USU Medan. 2015

25. Purwanto A \& Taftazani BM. Pengaruh Jumlah Tanggungan terhadap tingkat kesejahteraan ekonomi keluarga pekerja K3L Universitas Padjadjaran. Jurnal Pekerjaan Sosial, 2018; 1(2): 33-43. 